\title{
The Conformity of Diagnostic Test Between Burrow Ink Test Method With Skin Scrapping Method of Scabies in Rabbit (Lepus domesticus)
}

\section{Uji Diagnosis Kesesuaian Antara Metode Tes Tinta Terowongan dengan Scrapping Kulit Terhadap Kasus Skabies pada Kelinci (Lepus domesticus)}

\author{
${ }^{1)}$ Fadila Zikri Amanda, ${ }^{2)}$ Poedji Hastutiek, ${ }^{3)}$ Emy Koestanti Sabdoningrum, ${ }^{2)}$ Nunuk Dyah R L, \\ ${ }^{2)}$ Endang Suprihati, ${ }^{4}$ Hana Eliyani \\ ${ }^{1)}$ Student, ${ }^{2)}$ Department of Parasitology Veteriner, ${ }^{3)}$ Department of Animal Husbandry, ${ }^{4}$ Department of \\ Anatomi Veteriner. Faculty of Veterinary Medicine, Universitas Airlangga.
}

\begin{abstract}
This study intend to know the conformity of diagnostic test between burrow ink test method with skin scrapping method of scabies in rabbit. Scabies caused by Sarcoptes scabiei which has a predilection in stratum corneum and lucidum. Clinical symptoms was characterized by papula or crusting of the skin. This study presents a laboratory explorative research with cross sectional approach. Samples used 20 rabbits that infested scabies naturally. Data obtained by performing diagnostic burrow ink test method and skin scrapping in rabbits which are infested scabies naturally. KAPPA test used as data analysis. Results showed that the number of positive results based on burrow ink test method are 12 rabbits and 8 rabbits are negative while skin scrapping obtained the positive results are 11 rabbits and 9 rabbits are negative. KAPPA test analysis performed on the overall study data was obtained 0,490 . The conclusion of this study is burrow ink test method has a good conformity with the skin scrapping in rabbits which are infested scabies naturally that can be used for diagnostic analysis of scabies with a simple method, faster, and have the same ability with skin scrapping without hurting animals.
\end{abstract}

Key words : burrow ink test, skin scrapping, scabies, Sarcoptes scabiei.

\section{Pendahuluan}

Skabies adalah penyakit kulit menular yang disebabkan oleh infestasi dari Sarcoptes scabiei. Penyakit ini sering disebut juga dengan kudis. (Handoko, 2008). Skabies merupakan penyakit yang banyak menjangkiti ternak, bahkan dapat menyerang manusia. Penularannya dapat terjadi melalui kontak langsung antar hewan penderita bahkan kontak tidak langsung yaitu melalui peralatan yang terkontaminasi (Eleser et al., 2005).

Diagnosis skabies yang berlaku selama ini masih didasarkan pada gejala klinis dan pemeriksaan mikroskopis dari scrapping kulit yang menunjukkan gejala krusta atau keropeng, hal tersebut menyebabkan adanya kesulitan pada saat menangani ternak dan menyalahi secara etik karena untuk pemeriksaan adanya tungau diper- lukan scrapping kulit sampai timbul bintik-bintik darah. Tungau tidak selalu mudah ditemukan dan umumnya dengan scrapping ditemukan positif sekitar 30-50\%. Pada manusia, seringkali merasa enggan apabila dilakukan scrapping pada kulitnya (Wahyuti dkk., 2009).

Diagnosis tanpa menimbulkan bintik-bintik darah dan tidak menyakiti hewan adalah dengan tes tinta terowongan. Tes tersebut diawali dengan meneteskan tinta cina pada papula skabies yang merupakan massa padat menonjol di permukaan kulit bagian stratum korneum dan berwarna merah yang selanjutnya segera dihapus menggunakan alkohol. Tinta cina yang telah dihapus tersebut akan membentuk terowongan yang merupakan jejak dari $S$. scabiei. Jejak terowongan akan terlihat sebagai garis yang berkelok-kelok atau zig-zag (Murtiastutik, 2008). 
Pemeriksaan dengan tes tinta terowongan telah dilakukan pada manusia (Hoedojo, 1989) sehingga belum dilakukan penelitian pada hewan serta belum dapat diketahui mengenai hasil pemeriksaan tersebut sesuai atau tidak sesuai dengan scrapping kulit.

Berdasarkan latar belakang di atas, maka perlu dilakukan penelitian tentang uji diagnosis kesesuaian antara metode tes tinta terowongan dengan scrapping kulit terhadap kasus skabies pada kelinci.

\section{Metode Penelitian}

Penelitian ini telah dilakukan di Laboratorium Entomologi dan Protozoologi Departemen Parasitologi Fakultas Kedokteran Hewan Universitas Airlangga serta Kandang Hewan Coba pada bulan September hingga November 2015.

Hewan coba yang digunakan berupa kelinci lokal (Lepus domesticus) yang terinfestasi skabies secara alami baik jantan maupun betina berumur 7-8 bulan sebanyak 20 ekor yang didapat dari Peternakan Kelinci Gunungsari Kota Batu.

Alat yang digunakan dalam penelitian ini berupa sarung tangan plastik (glove), kapas, kaca obyek, kaca penutup, cawan petri, mikroskop, scalpel, dan pipet.

Bahan utama pada penelitian ini adalah papula kulit kelinci yang terinfestasi skabies secara alami, tinta cina, $\mathrm{KOH} 10 \%$, Alkohol $10 \%$, dan Betadine.

\section{Identifikasi Sarcoptes scabiei}

Cara mengidentifikasi S. scabiei dilakukan dengan tes tinta terowongan dan scrapping kulit. Pada tes tinta terowongan dilakukan dengan pemberian tinta cina pada kulit yang terinfestasi skabies. Tinta cina akan menutup permukaan kulit, diamkan selama 20-30 menit, kemudian tinta diusap dengan kapas yang telah dibasahi alkohol $70 \%$. Tes dinyatakan positif apabila tinta cina masuk ke dalam terowongan dan membentuk gambaran khas berupa garis zig-zag (Hoedojo, 1989).

Metode scrapping kulit dilakukan dengan pengerokan pada kulit yang terinfestasi skabies yang sebelumnya telah dilakukan diagnosis dengan metode tes tinta terowongan. Kerokan tersebut dijernihkan dengan larutan $\mathrm{KOH} 10 \%$, diletakkan pada objectglass, kemudian ditutup dengan coverglass dan diperiksa dengan mikroskop pada perbesaran 10-40 kali (Iskandar, 1989).

\section{Rancangan Penelitian}

Penelitian ini menggunakan rancangan penelitian Eksplorasi Laboratorik yang selanjutnya dilakukan pendekatan cross sectional dan pengukuran kesesuaian dengan analisis statistik menggunakan Uji Kappa.

\section{Hasil dan Pembahasan}

Hasil pengujian diagnosis metode tes tinta terowongan dan scrapping kulit pada kelinci yang terinfestasi skabies secara alami, disajikan pada Tabel 1.

Tabel 1. Data Hasil Pemeriksaan Diagnosis dengan Metode Tes Tinta Terowongan dan scrapping Kulit

\begin{tabular}{cccc}
\hline No. & $\begin{array}{c}\text { Kode } \\
\text { Sampel }\end{array}$ & $\begin{array}{c}\text { Metode Tes } \\
\text { Tinta } \\
\text { Terowongan }\end{array}$ & Scrapping \\
\hline 1. & $\mathrm{~K}_{1}$ & 12 & 11 \\
2. & $\mathrm{~K}_{2}$ & 8 & 11 \\
3. & $\mathrm{~K}_{3}$ & 8 & 9 \\
4. & $\mathrm{~K}_{4}$ & 12 & 11 \\
5. & $\mathrm{~K}_{5}$ & 12 & 11 \\
6. & $\mathrm{~K}_{6}$ & 12 & 11 \\
7. & $\mathrm{~K}_{7}$ & 8 & 11 \\
8. & $\mathrm{~K}_{8}$ & 12 & 11 \\
9. & $\mathrm{~K}_{9}$ & 8 & 9 \\
10. & $\mathrm{~K}_{10}$ & 8 & 9 \\
11. & $\mathrm{~K}_{11}$ & 12 & 9 \\
12. & $\mathrm{~K}_{12}$ & 12 & 9 \\
13. & $\mathrm{~K}_{13}$ & 12 & 11 \\
14. & $\mathrm{~K}_{14}$ & 8 & 9 \\
15. & $\mathrm{~K}_{15}$ & 8 & 9 \\
16. & $\mathrm{~K}_{16}$ & 12 & 9 \\
17. & $\mathrm{~K}_{17}$ & 12 & 11 \\
18. & $\mathrm{~K}_{18}$ & 8 & 9 \\
19. & $\mathrm{~K}_{19}$ & 12 & 11 \\
20. & $\mathrm{~K}_{20}$ & 12 & 11 \\
\hline
\end{tabular}

Keterangan:

$(+)$ : Terdapat garis lurus atau zig-zag dari tinta cina yang berpenetrasi ke dalam terowongan kulit pada papula skabies pada tes tinta terowongan, ditemukan tungau Sarcoptes scabiei di bawah mikroskop pada metode scrapping kulit, 
(-): Tidak terdapat garis lurus atau zig-zag dari tinta cina yang berpenetrasi ke dalam terowongan kulit pada papula skabies pada tes tinta terowongan, tungau Sarcoptes scabiei tidak ditemukan di bawah mikroskop pada metode scrapping kulit.

Hasil positif pada metode tes tinta terowongan didapatkan sebanyak 12 ekor dan hasil negatif sebanyak 8 ekor sedangkan hasil positif pada scrapping kulit berjumlah 11 ekor dan 9 ekor adalah hasil negatif. Hasil positif dan negatif ditunjukkan pada Gambar 1.
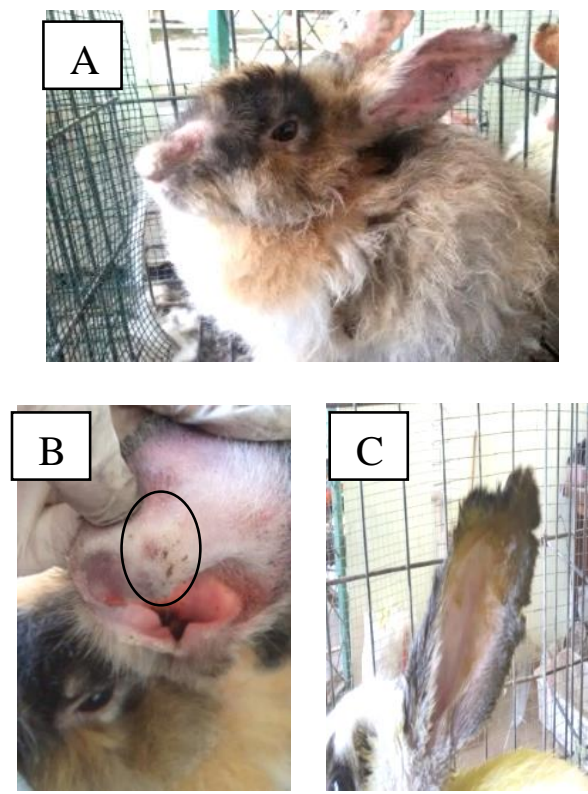

Gambar 1. Kelinci Dengan Hasil Positif pada Pemeriksaan Tes Tinta Terowongan (A) Terlihat Garis Zig-zag dari Tinta Cina yang Berpenetrasi ke Dalam Terowongan (B) dan Hasil Negatif Skabies (C) pada Tes Tinta Terowongan Menggunakan Kamera Dengan Resolusi 2 Megapixel Tanpa Perbesaran.

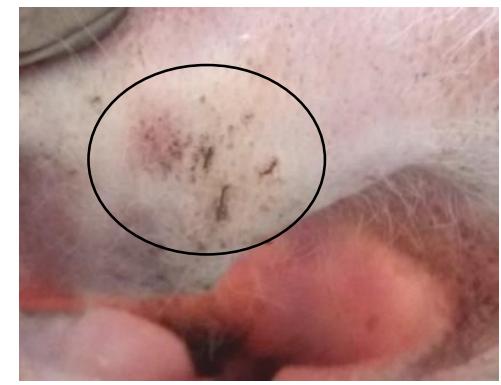

Gambar 2. Garis Zig-zag dari Tinta Cina yang Berpenetrasi ke Dalam Terowongan dari Sampel Kelinci Yang Terinfestasi Skabies dengan Tes Tinta Terowongan Menggunakan Kamera dengan Resolusi 2 Megapixel Perbesaran 4x.

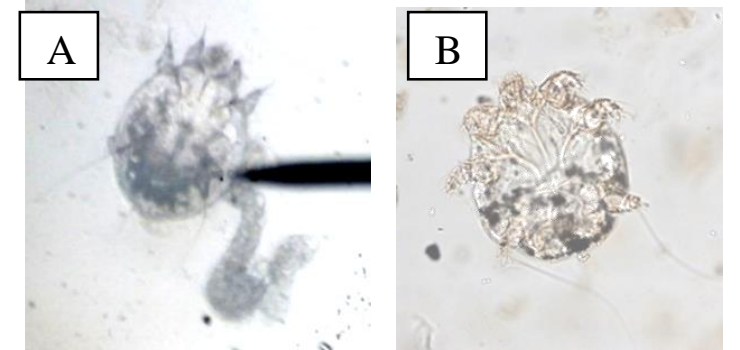

Gambar 3. A. Sarcoptes scabiei dan B. Notoedres cati var. cuniculi Yang Ditemukan Pada Sampel Kelinci Melalui scrapping Kulit Setelah Diamati Dengan Bantuan Mikroskop Perbesaran 100-40o Kali.

Penelitian ini didapatkan hasil yang sesuai dengan pernyataan Iskandar (2000) yang dilakukan pada manusia, bahwa tes menunjukkan hasil positif pada metode tes tinta terowongan bila tinta masuk ke dalam terowongan papula yang pada bagian tengahnya terdapat alur panjang akibat aktivitas menggali dari tungau betina sehingga selanjutnya mengakibatkan terbentuknya garis lurus atau zigzag karena terabsorbsinya tinta cina tersebut.

Hasil metode scrapping kulit pada kambing menurut Manurung (2001) sesuai dengan hasil yang didapatkan pada penelitian ini bahwa scrapping dinyatakan positif apabila ditemukan tungau S. scabiei di bawah mikroskop setelah dilakukan pengerokan kulit (Handoko, 2001).

Hasil tes tinta terowongan dan scrapping kulit dilakukan analisis menggunakan uji Kappa untuk mengetahui tingkat kesesuaian antara metode tes tinta terowongan dengan scrapping kulit. Analisis dengan Uji Kappa bertujuan untuk mengukur kesesuaian di antara dua atau lebih objek yang dimasukkan ke dalam perhitungan statistik untuk pencarian fakta yang akan diamati dengan sesuai atau tidak sesuai (Viera et al., 2005).

Perhitungan uji Kappa didapatkan nilai yaitu 0,490 yang selanjutnya disesuaikan dengan tabel interval uji statistik kappa menyatakan bahwa nilai tersebut memiliki kesesuaian yang baik dengan scrapping kulit. Kesesuaian yang baik memiliki arti bahwa antara tes tinta terowongan dengan scrapping kulit memiliki tingkat kesesuaian yang hampir mendekati sempurna.

Metode tes tinta terowongan dapat dinyatakan memiliki kesesuaian yang baik dengan scrapping kulit karena keduanya memiliki ke- 
mampuan yang sama dalam mengetahui adanya tungau. Metode tes tinta terowongan mengetahui adanya tungau melalui aktivitas yang diakibatkan tungau yaitu adanya terowongan pada papula skabies sehingga dapat menjadi jalan tinta cina ketika dilakukan pemeriksaan sedangkan scrapping kulit mengetahui adanya tungau melalui ditemukannya tungau $S$. scabiei di bawah mikroskop dengan perbesaran 10-40 kali pada hasil pengerokan papula skabies pada bagian superficial kulit. Kedua metode tersebut mempunyai kemampuan yang sama-sama sesuai untuk mendiagnosis penyakit skabies pada hewan sesuai dengan hasil uji kappa yang telah dianalisis, namun perbedaannya adalah pada metode tes tinta terowongan membutuhkan alatalat yang lebih sederhana, waktu yang digunakan lebih efisien, dan tidak menyakiti hewan.

\section{Kesimpulan}

Metode tes tinta terowongan memiliki kesesuaian yang baik dengan scrapping kulit pada kelinci yang terinfestasi skabies secara alami dengan didapatkan nilai o,49o sesuai Tabel Interval Uji Kappa.

\section{Daftar Pustaka}

Eleser, S., Junjungan, J., Manurung dan T. Suibu. 2005. Efektivitas pemberian monolaurin dan obat alternative lainnya dalam memberantas penyakit skabies pada kambing. Pros. Seminar Nasional Peternakan dan Teknologi Veteriner, Bogor, 12-13 September 2005. Puslitbang Peternakan, Bogor. Hal 941-945.

Handoko, R. 2001. Diagnosis Skabies dengan laboratorium dan Tinta. Maj. Parasitol. Ind. 2 (3). Page: 91-96.Hoedojo. 1989 Diagnosis Skabies dengan Tinta. Majalah Parasitol. Indonesia 2 (3-4). Page 91-96

Iskandar, T.,J. Manurung dan S.J. Simanjuntak. 1989. Penyakit pada Kelinci. Latihan Keterampilan Budidaya Kelinci. Badan Pendidikan Latihan dan Penyuluhan Pertanian Cihea - Cianjur. Puslitbang Peternakan, Bogor. Hal $262-266$.

Manurung, J. 20o1. Kudis. Petunjuk Teknis Penyakit Hewan. Balai Penelitian Veteriner. Badan Peneliti dan Pengembangan
Pertanian. Departemen Pertanian. Hal. 5359

Murtiastutik D., 2008. Skabies. In: Barakbah J., Lumintang H., dan Martodiharjo S. Ed. Buku Ajar Infeksi Menular Seksual. Airlangga University Press, Surabaya. Hal 202-208.

Viera, A.J., Garret, J.M. 2005. Understanding Interobserver Agreement: The Kappa Statistic, Fam Med; 37 (5). Page: 360-3.

Wahyuti, R.N., N.D. Retno dan E. Suprihati. 2009. Identifikasi Morfologi dan Profil Protein Tungau Sarcoptes scabiei pada Kambing dan Kelinci. Penelit. Med. Eksakta 8 (2). Page: $94-11$ 